\title{
THE RELATIONSHIP BETWEEN THE SCHOOL'S ORIGIN AND ENGLISH PROFICIENCY AT MIDDLE CLASS LEVEL OF FOOD AND BEVERAGE SERVICE OF STPBI
}

\author{
Firlie Lanovia Amir, I Gede Putu Widarmana, Wayan Rena Mariani, Ni Made \\ Rinayanthi. \\ Sekolah Tinggi Pariwisata Bali Internasional \\ gedewidarmana@yahoo.com, made.rina10@gmail.com
}

\begin{abstract}
English in the era of globalization has a very important role, especially in the working industry. Almost all types of jobs require English proficiency, especially in tourism area. As the most demanding international language in hospitality industry, English is taught as the main menu in the tourism school in a various majors, including the food and beverage service, both in the context of active and passive English. Tourism Schools, especially food and beverage service major, has become a target from those who just graduate from SMA and SMK. In the curriculum of both SMA and SMK, they have been taught English language both in general and in terms of tourism. After that they will get the broader English base on their major in the tourism school. For this reason this study was conducted to determine the relationship between the schools' origin and English proficiency at middle class level of Food and Beverage Service of STPBI. This study uses Leven's test analysis which is then descriptively translated to clarify data acquisition. By using SPSS 16.0 it was obtained $t$ calculation, 0.544, that the value is greater than the level of significance, 0.05, which means that the school's origin does not significantly affect the students' English proficiency at middle class level of Food and Beverage Service of STPBI. It is quite reasonable for both the SMA and SMK, English is taught by the same order of curriculum, either with KTSP and K13, which adopt teaching English communicatively. The difference is; English is taught in general manner in SMA, while in SMK, English is taught in specific way based on their major. However, the duration of their learning in the classroom is less that SMA, where SMK need to conduct their training section in the industry. On the same side, classroom English lessons in both SMA and SMK are not often taught by using full English, but rather using partly Indonesian or even worst, fully Indonesian. Meanwhile in the food and beverage major, they are taught English by the same means and methods, resulting in equality of the subject comprehension. The equality can also be seen from a thin difference on their mean value of their English proficiency in the class. It is concluded that the schools' origin does not determine the level of English proficiency at middle class level of Food and Beverage Service of STPBI. Hopefully this research can be used as reference
\end{abstract}


methods of teaching English in the classroom so that students can get equal opportunity regardless their schools' origin.

\section{INTRODUCTION}

In the current world of globalization, English is deemed important almost in all aspects, especially in working industry, not to mention the hospitality business. This is true since many people from various background travel around the world and interact to others. This made English as an international language very important to them to communicate and easier to get mutual understanding.

As a booming field, tourism has become one of the most desirable fields to work in for our youngsters that are just graduating from high school, SMA or SMK. The opportunity to interact to foreigners as well as having considerably decent amount of payment has become their motivation to work in the hospitality industry. One of among interested fields in tourism industry is food and beverage service. This field is consider the most important industries in the world economy, which worth approximately US 4.22 billion and employs about 4.4 million people working in Europe Union alone (Letizia. 2005). Considering the importance, employees in the sector need decent English proficiency, both active and passive. One way to get the certain qualification is by trusting their initial training in tourism school.

Tourism school is primarily design to meet the requirement of skills and foreign language proficiency at the same time. In food and beverage service major, English is also taught to meet the requirement. To pursue their desire to work in the industry, middle school graduations is trying very hard to enter the tourism school. Their backgrounds were varied. Some are coming from SMA (general high school) and others are coming from SMK (Vocational schools). Although SMA and SMK are currently applying the same curriculum, the 2013 Curriculum and the KTSP, but as we know there is a slight difference in executing classroom teaching method. Those who come out of general high school have general English, which means their school has taught the language in general way, whether it's vocabulary, grammar, style, and other aspects of the English language. In contrary, SMK graduations were taught English in particular way based on their majors. For example, those with a front office major were taught the English language with FO vocabulary. Likewise, students who majored in food and beverage service were taught within their majors in Food and Beverage Service area.

From the explanation above can be seen that the Students' English background who study in the tourism school are quite diverse. Logically, their mastery in English language are also different. But during their studying in the tourism school, they were taught relatively same techniques and methods of teaching English, namely in accordance with the curriculum and policy adopted by the particular tourism school. In this regards, students of Food and Beverage Service of STPBI are also treated the same in learning English, regardless their school's origin, whether they are coming from general high or vocational school. Therefore the present study is made to determine whether there is a relationship between student's school's origin (high school and vocational school) and English language skills at the middle level of Food and Beverage Service at STPBI. The 
research objective is of course to determine whether there is a relationship between student's school's origin (high school and vocational school) and English language skills at the middle level of Food and Beverage Service at STPBI.

\section{Hypothesis:}

There are two formulated hypotheses for this study, namely;

1. H0: there is not any relationship between the school's origin and the English language skills

2. H1: there is a correlation between the school's origin and the English language skills

\section{LITERATURE REVIEW}

\section{The Curriculum of SMA and SMK}

There are two types of curriculum used by secondary education level, either in the general high school or vocational school, in Indonesia at this time. The first curriculum is called KTSP (Kurikulum Tingkat Satuan Pelajaran) created in 2006 and based on Regulation Number 20 Year 2003 on National Education System, and the Indonesian Government Regulation No. 19, 2005 on National Education Standards (BNSP. 2006), stated that the purpose of secondary education in the curriculum is to improve the intelligence, knowledge, personality, character, and skills to live independently and to follow further education, while the purpose of vocational education is to improve intelligence, knowledge, personality, character, and skills to live independently and to follow further education in accordance with the vocational. It can be seen here that the purpose of education in the KTSP curriculum, both general high school and vocational school have something in common, with only a slight difference because the lessons in SMK is focusing on skills/expertise.

Later in 2013, based on Regulation of Minister of Education number 70, 2013 on the Basic Framework and Curriculum Structure of Vocational High School/Vocational of Madrasah Aliyah, 6 years old KTSP was eventually replaced by Curriculum 2013 (Kemdikbud. 2013). The initial application of this curriculum is limited to 6,326 schools across Indonesia that are said to be the pioneer school. Most other schools are still using KTSP while waiting for the next instruction from the new curriculum implementation. But at the end of 2014, the government through the new Minister of Education, Anies Baswedan, instructed temporary suspension of Curriculum 2013 as a result of protests from various parties for the implementation of Curriculum 2013 that it feels to be rushed and less preparation (Rinaldi, 2014).

In effect of the suspension, most schools that were (less than 3 semesters) implementing the curriculum 2013 were turning back to use KTSP. Until presently, evaluation and training of teachers regarding curriculum 2013 is still in progress, causing dualism curriculum implementation in Indonesia. However, SMA and SMK are still consider as a secondary education, as mentioned in the Education Minister Regulation number 70, 2013, " SMK / MAK curriculum is designed with the view that the SMA / MA and SMK / MAK is basically a secondary education, distinguishing only in accommodating interest of the learners when entering secondary education. Therefore, the general structure of 
SMK / MAK is the same as the general structure of SMA / MA, that are three groups of subjects: Group A, B, and C" (Kemdikbud. 2013).

\section{English proficiency in Food and Beverage Service}

As what have been mentioned previously, food and beverage service has become the largest part of industry in the tourism industry as a whole (Letizia. 2005). To support a large industry is required highly competent workforces, both in terms of governance skills of the course itself and communication primarily using the International language, English. According to a study conducted by the New Zealand Tourism Research Institute (NZTRI. 2007), it is known that a bad mastery of the English language is influencing service and productivity area, especially when there is a reservation via telephone. Even there was a Chef with poor English can cause conflicts with staffs. Besides, the customers will be very annoyed with staffs who cannot speak English well, which of course will reduce the level of customers' satisfaction at the venue.

English that should be mastered by students of Food and Beverage Service is English in the category of ESP (English for specific purposes). According to experts, ESP is an approach to teaching the language in which the teaching methods and content are depending on the reason for the learners. In addition, ESP is studied by adults who have learned English language and want to increase their knowledge to communicate professionally and in certain occupations (Hutchinson and Waters, 1987. Lorenzo, 2005. In Chia-Hui Lin et al 2013).

There are four English language domains that must be mastered by the students of Food and Beverage Service. All four are; 1) Listening. Students are expected to evaluate, process, or interpret speech in any situation. 2) Speaking. Students are expected to demonstrate the ability of oral speech in various situations for specific purposes. 3) Reading. Here, students are expected to evaluate, process, interpret written language, symbols or text. 4) Writing. The last domain aims to make students able to demonstrate the ability of communication in writing in form and purpose (Chia-Hui Lin et al, 2013). Chia added, by citing Spolsky (1989), in studying English as a second language, learners are initially practice and develop listening and reading skills, before stabilizing to a higher level, namely Speaking and Writing skills.

\section{METHODOLOGY}

This study uses quantitative data analysis with normality test procedures and Leven Test (Two Independent Sample Test) with the help of SPSS 16.0, to determine the relationship between the schools' origin with English language skills of middle level Food and Beverage Service students of STPBI. The subjects as well as the population of the research are 60 middle level students of Food and Beverage Service of STPBI, where 34 of them are vocational school graduates and 26 others are general high school graduates. Research instrument used are English posttest results for two semesters (1 and 2), observation sheets, questionnaires, and interviews to measure and determine the origin of the school, classroom teaching method by their former teachers. Later the of the data will be combined with the results of qualitative findings from the instruments for later described in narrative form so that the data acquisition are more clearly and provide reasons for numeric data. 


\section{RESULTS}

From the subjects' posttest results of their English language skills for 2 semesters, it was found out that the mean ratio between general high and vocational school students are; 77.2 (for SMA) and 76.9 (for SMK). When viewed from both mean comparison, we can conclude, roughly, that there is a difference in English ability levels between those from SMA and SMK. It can be seen that students from SMA graduates have a slightly higher mean value than those from vocational school, with a slight mean difference of approximately 0.3 . But to find out whether these differences are significant in a statistical standpoint, it is necessary to conduct further test.

\begin{tabular}{|c|l|l|l|l|}
\hline $\begin{array}{c}\text { School's } \\
\text { Origin }\end{array}$ & $\mathrm{N}$ & Mean & $\begin{array}{l}\text { Std. } \\
\text { Deviation }\end{array}$ & $\begin{array}{l}\text { Std. Error } \\
\text { Mean }\end{array}$ \\
\hline Scores SMK & 34 & 76.9265 & 5.08136 & .87145 \\
SMA & 26 & 77.2115 & 5.77957 & 1.13347 \\
\hline
\end{tabular}

The first test conducted was test of normality, which serves to determine whether the data error are normal or not. By using SPSS 16.0 it was found out that the data obtained are normal, with Kolmogorov-Smirnov sig. of 0.019, which is larger with significant value that has been determined, 0.05 .

\begin{tabular}{|lc|l|l|l|l|l|l|}
\hline & \multicolumn{3}{|l|}{ Kolmogorov-Smirnov } \\
& & Statistic & df & Sig. & Statistic & df & Sig. \\
\hline $\begin{array}{l}\text { Residual } \\
\text { Scores }\end{array}$ & for & .126 & 60 & .019 & .964 & 60 & .074 \\
\hline
\end{tabular}

With the already-determined normal data, then the next test is to conduct Levene's test to determine the significance value between the two groups (high and vocational school). From the test results, it is found out the results of Leven's test has sig. value of 0.544 , which of course is greater than the significance value of the 0.05 . Thus from the test results it can be concluded that there is not any difference in scores value between the two groups, or in other words, H0 hypothesis is accepted (there is not any difference between the origin of the school with the English ability in middle level class of Food and Beverage Service in STPBI) and, of course, H1 hypothesis is rejected. 


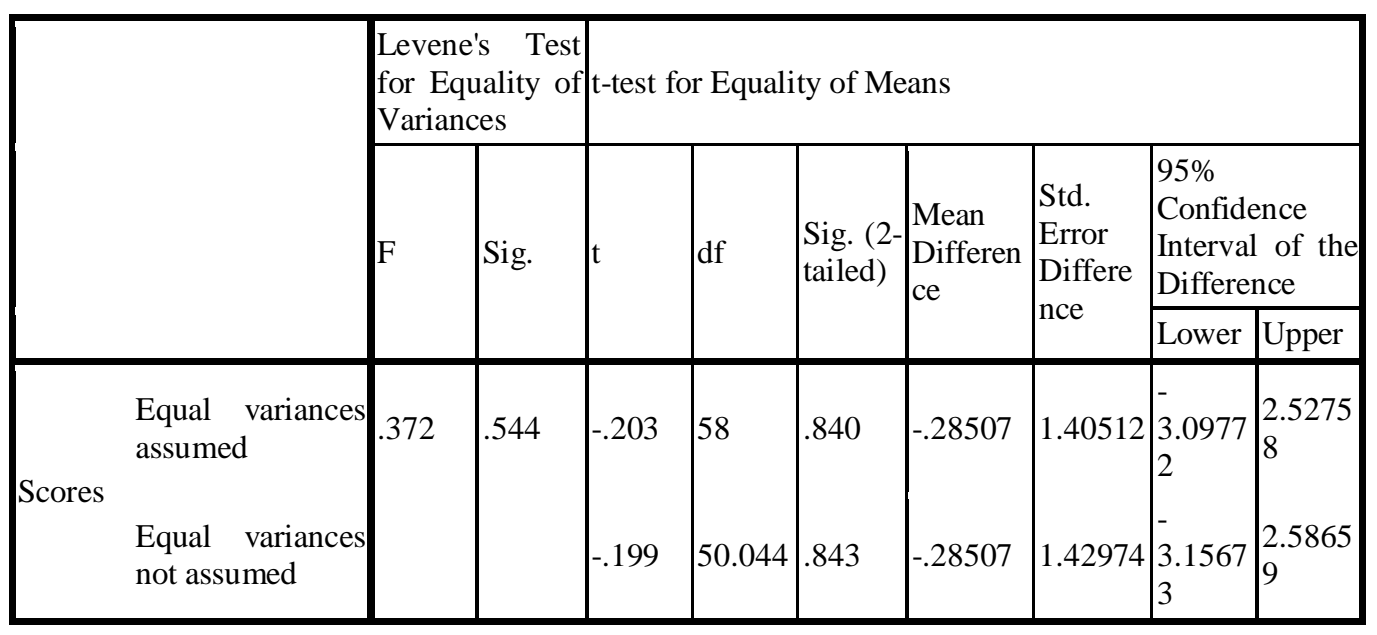

As what have been explained previously, the mean difference is not significant due to the same curriculum for English teaching in both SMA and SMK. There are two current curriculums use at the general high and vocational school level, KTSP and Curriculum 2013. Both curriculums are characterized by more or less the same, which teaches English in communicative manner. Students are required to actively using current English practically and pragmatically, without stick on teaching structure and grammar. It is expected that students can either use English communicatively both in oral and written form (Productive skills, namely the Speaking and Writing), without also leaving other aspects of their receptive skills, namely listening and reading.

The second similarity between SMA and SMK graduates is in term of teaching English in the classroom. Based on the results of interviews with the subjects, both SMA and SMK graduates said they did not fully get the English language in the class. English teachers usually teach English using Indonesian and very little English. Moreover, in the technique of presenting the materials are somewhat monotonous that rely on student worksheets, so the communicative purpose of the curriculum is not attainable. As the result, students become less able to communicate actively in English, both speaking and writing.

There are fundamental differences that are owned by SMA and SMK, which one of them is the teaching material. In the high school level, English is taught in general way. The materials, both in the guidebook and student worksheet, are of a general nature, even their worksheets are also includes general English vocabulary. In terms of tourism, they could get some vocabularies or tourism terms from some materials related to the world of tourism, considering tourism are quiet be a familiar materials in many schools in Bali, so it is often included in teaching English. But the intensity of the materials obtained by high school students are not that much.

In SMK, the English Subject materials are reserved in accordance with the students' majors. The problem might really lies in the many departments in SMK. There are engineering, building, administration, and also tourism department. Those majors' diversity in SMK mean, in certain manner, a diverse ad wide range of acquiring English skills by the students. Like engineering for example, English is taught only in the technical area alone, which means it is far from the tourism 
matter. This resulted in less English language skills in terms of tourism sector. Unlike the case of students who come from vocational tourism school, which has certain excellent English language skills in tourism, rather than the ones from nontourism majors.

On the other hand, students from SMK tend to get less duration English language class than students from general high school. This is because the vocational students have to spend their time in the training/internship program in the industry according to the department. But the possibility of such students to learn English in the workplace is enormous, especially in industries that are in direct contact with English language, such as when they intern in a hotel or restaurant. English that is derived directly from the industry is generally better and more practical because it is used in the immediate real context, unlike English in classrooms that is generally up to a simulation only.

Upon entering tourism schools, both high school and vocational school students get the same English curriculum and teaching techniques. From the equality, previous teaching difference when they are in SMA and SMK seems has no meaning anymore, and they gain knowledge of English language with the same opportunity. Therefore it can be ascertained that the data obtained and analyzed are quite accurate, giving a reason to the conclusion that there is not any connection between the schools' origin and English language skills in middle level students of Food and Beverage of STPBI.

\section{CONCLUSIONS AND SUGGESTIONS Conclusion}

The existence of the English language in the world of tourism is undoubtful, especially in the areas of food and beverage Service as a top contributor to the tourism industry. To realize their dream of working in the world for tourism, secondary school graduates, whether from SMK or SMK, are trying to enter the tourism school that became the starting gate before entering the workforce. Later on they will be given the same English language material regardless the origin of their previous schools. But what becomes a concern was whether their English mastery are different based on their School's origin. Based on research that has been done, it is obtained that there is not any connection between students from high school graduates or vocational school graduates and English language skills at the middle level of Food and Beverage Service class of STPBI. Several reasons may underlie these findings.

The first reason is the method of teaching given by their teachers at the secondary school. Most English teachers in secondary schools teach by using partial English speaking. This means that they are taught by using Indonesian language, even some with mother tongue. The second reason is the English class duration is relatively the same. In high school, English was taught in general manner and full time during their schools time. Unlike the SMK, English are taught in accordance to their majors, but the time must be adjusted for their apprenticeship / job training program in industry related to their majors.

The last reason is the English procedures, materials, and methods of teaching given in tourism school are relatively the same, so logically English skills of each student will be the same. With some of these conditions, it turns out there is not any relationship between the students school's origin who come from 
high school and vocational school and the English language skills at middle level class of Food and Beverage Service Program of STPBI.

\section{Suggestion}

It is expected by this research, lecturers, tutors, or teachers in the tourism school keep treating the student with the same teaching methods so that English skills are equally obtained. As for the students, they do not have to feel uncomfortable to study hospitality in tourism school for either they have common English background or considering less vocabulary in tourism English for nontourism vocational school graduates, because students will be taught tourism English in a good way, so they will have a standard English language skills based on the needs of tourism industry.

\section{REFERENCES}

BNSP. 2006. Panduan Penyusunan Kurikulum Tingkat Satuan Pendidikan Jenjang Pendidikan Dasar dan Menengah. Retrieved from: http://bsnpindonesia.org/id/wpcontent/uploads/kompetensi/Panduan_Umum_KTSP.pdf

BNSP. 2013. StrukturKurikulum-SMK-MAK. Retrieved from: http://luk.staff.ugm.ac.id/atur/bsnp/Permendikbud70-2013KDStrukturKurikulum-SMK-MAK.pdf

Chia-Hui Lin, Wen-Chih Wu, Yin-Tsuo Huang. 2013. English for Specific Purposes (ESP) for Hospitality College Students and Hotel Employees in Taiwan. International Journal of Education and Research Vol. 1 No. 8 August 2013. Retrieved from: http://www.ijern.com/journal/August2013/15.pdf

Gallacci, Letizia. 2005. Food and Beverage. eMarket Services. Italy. Retrieved from;

http://www.emarketservices.com/clubs/ems/prod/report050801_food\%20an d\%20beverage.pdf

NZTRI. 2007. Food \& Beverage Service Sector Productivity Study. Prepared for The Workplace Group, New Zealand Department of Labour. AUT University. Retrieved from: http://employment.govt.nz/er/bestpractice/productivity/researchreports/food beverage/food-and-beverage.pdf

Penfold, Paul. 2014. Manual on Module IV - Customer Relations and Services. Fine-tuned version. Copyright: The Government of the Hong Kong Special Administrative Region. Retrieved from: http://www.edb.gov.hk/attachment/en/curriculumdevelopment/kla/pshe/nss-curriculum/tourism-and-hospitalitystudies/Customer_English_2014_01_28.pdf 
Rinaldi, Randa. 2014. Anies Baswedan Tetap Hentikan Penerapan Kurikulum 2013. Retrieved from: http://nationalgeographic.co.id/berita/2014/12/aniesbaswedan-tetap-hentikan-penerapan-kurikulum-2013 